\title{
NO-donors induce cross talk between cGMP and CAMP in signalling to human atrial L-type $\mathrm{Ca}^{2+}$ current
}

\author{
Nadiia Rozmaritsa*, Torsten Christ, Erich Wettwer, Ursula Ravens \\ From 5th International Conference on cGMP: Generators, Effectors and Therapeutic Implications \\ Halle, Germany. 24-26 June 2011
}

\section{Background}

Cardiac NO-activated pathways are discussed to involve cross-talk between cGMP and cAMP signalling [1,2]. Here we have investigated the signalling pathways relating to NO-donor $\mathrm{S}$-nitroso- $\mathrm{N}$-acetylpenicillamine (SNAP) modulation of L-type $\mathrm{Ca}^{2+}$ current $\left(\mathrm{I}_{\mathrm{Ca}, \mathrm{L}}\right)$ in human right atrial cardiomyocytes.

\section{Material and methods}

Experiments were performed on human biopsy tissue from 62 patients in sinus rhythm. $\mathrm{I}_{\mathrm{Ca}, \mathrm{L}}$ was measured with whole-cell voltage-clamp technique.

\section{Results}

Application of SNAP $(100 \mu \mathrm{M})$ increased basal $\mathrm{I}_{\mathrm{Ca}, \mathrm{L}}$ from $5.93 \pm 0.23 \mathrm{pA} / \mathrm{pF}$ to $9.10 \pm 0.45 \mathrm{pA} / \mathrm{pF}(\mathrm{p}<0.001, \mathrm{n} / \mathrm{N}=117 /$ 62 ). The effect was abolished by inhibition of soluble guanylate cyclase (sGC) with ODQ $(30 \mu \mathrm{M})$, suggesting involvement of cGMP. Stimulator of sGC (BAY 41-2272, $10 \mathrm{nM}-10 \mu \mathrm{M})$ also increased $\mathrm{I}_{\mathrm{Ca}, \mathrm{L}}$ and this effect was potentiated in the presence of SNAP. Direct activation of protein kinase G (PKG) with 8-Br-cGMP $(100 \mu \mathrm{M}$, intracellular application) increased basal $\mathrm{I}_{\mathrm{Ca}, \mathrm{L}}$. However, not only cGMP but also cAMP was involved, because, the effect of SNAP on $\mathrm{I}_{\mathrm{Ca}, \mathrm{L}}$ was prevented with the protein kinase A blocker (Rp-8-Br-cAMP 1 mM, intracellular). Thus, cGMP may activate $\mathrm{I}_{\mathrm{Ca}, \mathrm{L}}$ via direct activation of PKG and indirect activation of PKA at the same time. It is known, that cAMP-mediated activation of PKA is regulated by cGMP via modulation of phosphodiesterases (PDEs). The selective PDE2 inhibitor EHNA $(10 \mu \mathrm{M})$ did

\footnotetext{
* Correspondence: nadiia.rozmaritsa@tu-dresden.de Department of Pharmacology and Toxicology, Dresden University of Technology, Dresden, 01307, Germany
}

not affect basal or SNAP-stimulated $\mathrm{I}_{\mathrm{Ca}, \mathrm{L}}$, therefore PDE2 does not regulate basal cAMP level. In contrast, PDE3 inhibition with cilostamide $(1 \mu \mathrm{M})$ increased basal $\mathrm{I}_{\mathrm{Ca}, \mathrm{L}}$, suggesting that PDE3 is involved in basal cAMP level regulation. Interestingly, the cilostamide-induced increase in $\mathrm{I}_{\mathrm{Ca}, \mathrm{L}}$ is blunted upon addition of SNAP, most probably via activation of PDE2 by SNAP-mediated cGMP increase (Figure 1). Similarly, SNAP blunted enhancement of $\mathrm{I}_{\mathrm{Ca}, \mathrm{L}}$ by PKA activation with isoprenalin $(1 \mu \mathrm{M} ; 18.07 \pm 1.12$ $\mathrm{pA} / \mathrm{pF}$ vs $23.06 \pm 1.36 \mathrm{pA} / \mathrm{pF}, \mathrm{p}<0.001, \mathrm{n} / \mathrm{N}=21-39 / 18)$, however, this effect was prevented by PDE2 inhibition with EHNA.

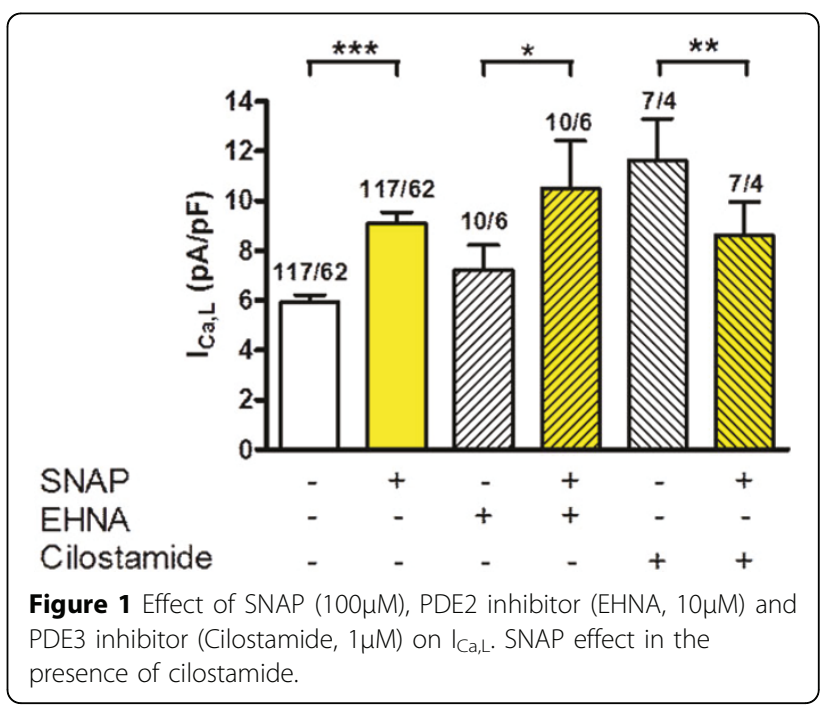

\section{Biomed Central}

(c) 2011 Rozmaritsa et al; licensee BioMed Central Ltd. This is an open access article distributed under the terms of the Creative Commons Attribution License (http://creativecommons.org/licenses/by/2.0), which permits unrestricted use, distribution, and reproduction in any medium, provided the original work is properly cited. 


\section{Conclusion}

We conclude that in human atrial cardiomyocytes NOdonors stimulate production of cGMP with further cross-talk to cAMP via PDE2 and PDE3.

Published: 1 August 2011

\section{References}

1. Castro LR, Schittl J, Fischmeister R: Feedback control through cGMPdependent protein kinase contributes to differential regulation and compartmentation of cGMP in rat cardiac myocytes. Circ Res 2010, 107:1232-1402.

2. Stangherlin A, Gesellchen F, Zoccarato A, Terrin A, Fields LA, Berrera M, Surdo NC, Craig MA, Smith G, Hamilton G, Zaccolo M: cGMP signals modulate cAMP levels in a compartment-specific manner to regulate catecholamine- dependent signaling in cardiac myocytes. Circ Res 2011, 108:929-939.

doi:10.1186/1471-2210-11-S1-P55

Cite this article as: Rozmaritsa et al.: NO-donors induce cross talk between CGMP and CAMP in signalling to human atrial L-type $\mathrm{Ca}^{2+}$ current. BMC Pharmacology 2011 11(Suppl 1):P55.

Submit your next manuscript to BioMed Central and take full advantage of:

- Convenient online submission

- Thorough peer review

- No space constraints or color figure charges

- Immediate publication on acceptance

- Inclusion in PubMed, CAS, Scopus and Google Scholar

- Research which is freely available for redistribution

Submit your manuscript at www.biomedcentral.com/submit
C Biomed Central 